Avoimesti luettavissa osoitteessa http://journal.fi/ainedidaktiikka

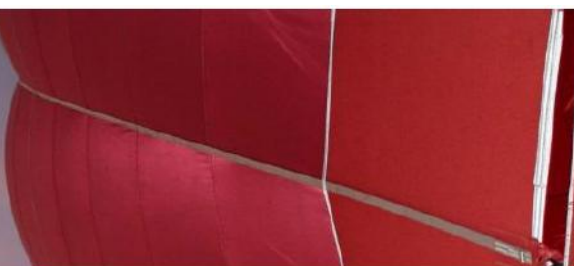

\title{
Käsityö ja asenteet - oppiaineen tulevaisuus
}

\author{
Antti Hilmola ja Ossi Autio \\ Kasvatustieteellinen tiedekunta, Helsingin yliopisto
}

Jo vuoden 1970 komiteanmietinnössä todetaan, että teknisen työn ja tekstiilityön opetuksen tulisi olla yhteistä koko ikäluokalle. Tämän jälkeen opetussuunnitelmaa on uudistettu useamman kerran, mutta koulutuspoliittisesti tarkoituksenmukaista ratkaisua käsityön opetuksen järjestämiseksi ei ole löytynyt. Tässä artikkelissa tarkastellaan oppilaiden asenteita käsityön oppiainetta kohtaan. Tutkimusaineisto on kerätty lukuvuoden 2013-2014 aikana. Tutkimusote on kvantitatiivinen ja aineisto $(N=982)$ on demografisesti koko maata edustava. Artikkelissa avataan käsityön opetuksen järjestämiseen liittyvää problematiikkaa ja teoreettiset lähtökohdat perustuvat aiempiin käsityön oppiaineen asenteisiin liittyvän tutkimuskirjallisuuden tarkasteluun. Varsinainen tutkimuskysymys on: Missä määrin tyttöjen ja poikien käsityön oppiaineeseen liittyvät asenteet ja käsitykset eroavat toisistaan? Tulosten perusteella teknisen työn sisältöjen painotettuun opetukseen osallistuneiden oppilaiden asenteet ovat selvästi myönteisempiä kuin saman sisältöiseen (yhtä paljon teknistä työtä ja tekstiilityötä) opetukseen osallistuneiden oppilaiden asenteet. Lisäksi painotettuun teknisen työn sisältöjen opetukseen osallistuneet oppilaat hakeutuvat muita useammin ja saman sisältöiseen opetukseen osallistuneet muita harvemmin käsityön valinnaiseen opetukseen. Edelleen tutkimuksen pohjalta voidaan esittää yksilön valinnan mahdollisuuksien kunnioittamisen näkökulmasta oikeutettu kysymys: Annetaanko kaikille oppilaille riittävä mahdollisuus painottaa kiinnostuksensa ja taipumuksensa mukaisia käsityön oppisisältöjä?

asenteet, sukupuoli, käsityön opetus, tekninen työ, tekstiilityö

Lähetetty: 10.2.2017

Hyväksytty 2.6.2017

Vastuukirjoittaja: antti.hilmola@helsinki.fi

orcid: 0000-0003-1025-0372 


\section{Johdanto}

Kansakoulussa opetettiin aikoinaan erikseen sekä poikien että tyttöjen käsityötä. Käsityö oli sukupuoleen sidottu oppiaine. Myöhemmin alettiin puhua sukupuolineutraalisti tai sukupuoliroolittomasti toteutettavasta käsityön opetuksesta (ks. esim. Pöllänen 2002). Sukupuolineutraalin käsityön opetuksen periaatetta alettiin painottamaan peruskouluun siirtymisen myötä ja vuoden 1970 komiteamietinnössä oppiaineiden nimitykset muutettiin sukupuolten välisen tasa-arvon nimissä tekniseksi käsityöksi ja tekstiilikäsityöksi, joiden opetukseen osallistumisen esteenä ei saanut enää olla oppilaan sukupuoli (Komiteanmietintö 1970: A5). Pian nimitykset lyhennettiin selkeyden vuoksi tekniseksi työksi ja tekstiilityöksi. Ajatus sukupuolineutraalista käsityön opetuksesta ei kuitenkaan ole toteutunut käytännössä, koska yksittäisellä oppilaalla on ollut mahdollisuus osallistua vain toisen käsityön eli joko teknisen työn tai tekstiilityön opetukseen. Tähän liittyen teknisen työn ja tekstiilityön sisällöllinen eriytyminen on ollut keskeinen kysymys niin tasa-arvon kuin opetuksen järjestämisen näkökulmista koko peruskoulun olemassa olon ajan ja näin ollen käsityön oppiaineen asemaa on pohdittu jokaisen opetussuunnitelmauudistuksen yhteydessä. Vuosituhannen vaihteessa tämä johti siihen, että vuosien 1994 ja 2004 opetussuunnitelmauudistusten keskeinen kysymys oli teknisen työn ja tekstiilityön yhdistäminen siten, että koko ikäluokalla olisi mahdollisuus osallistua molempien käsityön sisältöjen opetukseen. Pyrkimykset sukupuolineutraaliin ja tasa-arvoiseen käsityön opetukseen eivät toteutuneet tarkoitetulla tavalla.

Voimassa olevan perusopetuslain (POL 628/1998, 11§) mukaan käsityö on oppiaine, jossa yhdistyvät entiset oppiaineet tekninen työ ja tekstiilityö eli nykymuotoinen käsityö on kaksi erilaista käsityön sisältöaluetta eli sisältöä yhdistävä oppiaine. Tutkimusaineistonkeruun hetkellä käsityön opetus toteutettiin vuosiluokilla 1-4 saman sisältöisenä kaikille oppilaille käsittäen yhtä paljon teknisen työn ja tekstiilityön sisältöjä ja vuosiluokilla 5-9 opetus käsitti niin ikään kaikille oppilaille yhteisesti molempia sisältöjä, minkä lisäksi oppilaalle voitiin antaa mahdollisuus painottua käsityöopinnoissaan kiinnostuksensa ja taipumustensa mukaan joko tekniseen työhön tai tekstiilityöhön (Opetushallitus 2004, 244). Käytännössä tämä tarkoitti sitä, että paikallistasolla opetuksenjärjestäjä päätti, missä määrin vuosiluokilla 5-9 oppilaat osallistuivat molempien sisältöjen opetukseen ja missä määrin oppilailla oli mahdollisuus tehdä valintoja käsityön eri sisältöjen välillä. Saman sisältöisessä opetuksessa oppilas siis osallistui molempien sisältöjen opetukseen yhtä paljon. Painotetussa opetuksessa oppilaan tekemä valinta poissulki toisen sisällön opetukseen osallistumisen joko kokonaan tai osittain siten, että toisen sisällön opetukseen osallistuminen käsitti vain lyhyen vaihtojakson. Kuusi ym. $(2009,25)$ toteavat, että perusopetuksen käytännön organisointiin liittyvät päätökset tekee kunta ja koulu, minkä vuoksi käsityön opetusta on järjestetty eri tavoin kunnasta, alueesta, koulusta ja opettajasta riippuen. Syksyllä 2016 voimaan tulleiden 
perusopetuksen opetussuunnitelman perusteiden (2014) mukaan käsityön pakollinen oppimäärä ja taide- ja taitoaineiden valinnainen oppimäärä toteutetaan jatkossa siten, että teknisen työn tai tekstiilityön sisältöalueet eivät rajoita opetuksen toteuttamista, vaan yhteinen käsityö tarkoittaa monimateriaalista oppiainetta, jonka opetuksessa käytetään sekä teknisen työn että tekstiilityön työtapoja. Painotettua käsityön opetusta voidaan jatkossa toteuttaa vain kaikille oppiaineille tarkoitettujen valinnaisaineiden yhteydessä. (Opetushallitus 2014, Opetushallitus 2015.)

Opetuksenjärjestäjä voi päättää, että miten käsityön pakollinen oppimäärä jaetaan eri vuosiluokille kulloinkin voimassa olevan tuntijakoasetuksen mukaan. Vallitseva käytäntö lienee se, että käsityön kaikille pakollinen oppimäärä päättyy seitsemännen luokan jälkeen ja oppiaineen opiskelu kahdeksannella ja yhdeksännellä luokalla on valinnaista (Hilmola 2011). Tähän asti paikallisessa opetussuunnitelmassa käsityön pakollisen oppimäärän lisäksi varattua taide- ja taitoaineiden yhteistä opetusaikaa on voitu jakaa näiden aineiden kesken yhteisesti kaikille oppilaille tai se, taikka osa siitä, on voitu jättää oppilaskohtaisesti valittaviksi syventäviksi opinnoiksi (Opetushallitus 2004, 253). Yleinen käytäntö lienee ollut se, että taide- ja taitoaineiden yhteinen opetusaika on jätetty oppilaskohtaisesti valittavaksi valinnaisaineeksi, jossa valinnaista käsityön opetusta on toteutettu painotettuna oppilaan valinnan mukaan. Tiettyjen oppiaineiden valinnaisuus juontaa juurensa vuoden 1970 peruskoulu-uudistukseen, jolloin myös käsityöstä tuli valinnainen oppiaine perusopetuksen kahdeksannella ja yhdeksännellä luokalla (Kantola 1997, 48-49). Tuolloin kaikille oppilaille yhteisten aineiden joukosta poistettiin yläluokkien osalta sellaiset oppiaineet, kuten musiikki, kuvaamataito ja käsityö, joiden ei katsottu samassa määrin kuin ns. teoreettisten aineiden vaikuttavan silloisessa lukiossa menestymiseen (Komiteanmietintö 1970: A5, 22-23).

Vuonna 2010 perusopetuksen päättäneistä oppilaista 72 prosenttia (tytöt $47 \%$, pojat $98 \%$ ) oli osallistunut seitsemännellä luokalla teknisen työn sisältöjen ja 65 prosenttia (tytöt $90 \%$, pojat $39 \%$ ) tekstiilityön sisältöjen opetukseen. Näistä oppilaista 38 prosentin (tytöt $38 \%$, pojat $39 \%$ ) kohdalla opetus oli käsittänyt käsityön molempia sisältöjä. (Hilmola 2011.) Viimeisin ja vuoden 2016 elokuussa voimaan astuneet perusopetuksen opetussuunnitelman perusteet (2014) eivät enää lainkaan anna oppilaalle mahdollisuutta valita käsityön sisältöjä, vaan tämän jälkeen kyse on kaikille yhtä laajasta ja samanlaisesta tarjonnasta eli koko ikäluokkaa koskevasta "pakosta" osallistua sekä teknisen työn että tekstiilityön työtapoja sisältävään yhteisen käsityön opetukseen (vrt. Pöllänen 2002, 222). Vuoden 2004 opetussuunnitelmauudistuksen kynnyksellä Pöllänen (2002) näki siirtymisen yhteiseen käsityön oppiaineeseen siten, että sukupuolten tasa-arvon nimissä mekaanisen sukupuolineutraalisti toteutettu käsityön opetus eli samanlainen kohtelu tai opetusjärjestelyt voivat johtaa eriarvoisuuteen muilla alueilla. Yksilön valinnan mahdollisuuksia tulisi kunnioittaa itsensä toteuttamiseen, hyvinvointiin ja osallistumiseen liittyvistä syistä sekä oikeutena valita molempiin käsityölajeihin tutustuttavien perusopintojen lisäksi omia taipumuksia vastaavia syventäviä opintoja. (Pöllänen 2002, 223.) 


\section{Ainedidaktiikka 1(1) (2017)}

Aikaisemman tiedon mukaan käsityön sisältöjä koskevat valinnat ovat olleet vahvasti sukupuolisidonnaisia (ks. Hilmola 2011), mutta samalla on toteutunut oppilaan omia valintoja salliva mahdollisuuksien tasaarvo (ks. Pöllänen 2002). Viimeisin opetussuunnitelmauudistus tähtää vahvasti sukupuolineutraaliin käsityön opetukseen valintoja sallivan mahdollisuuksien tasa-arvon kustannuksella. Muutos on merkittävä ja tämä antaa aihetta tutkia ilmiötä tarkemmin sekä sukupuolen että yksilön tasa-arvon näkökulmista. Varsinainen tutkimuskysymys on: Missä määrin tyttöjen ja poikien käsityön oppiaineeseen liittyvät asenteet ja käsitykset eroavat toisistaan? Lisäksi tästä johdetaan alakysymys: Missä määrin tyttöjen ja poikien käsitykset hakeutua käsityön valinnaiseen opetukseen eroavat toisistaan?

\section{Käsityö, teknologiakasvatus ja asenteet}

Käsityön opetuksen yhteydessä puhutaan usein teknologiasta ja teknologiakasvatuksesta. Käsitteet liittyvät toisiinsa siten, että käsityö oppiaineena sisältää erilaisten teknologioiden opettamista. Parikan (1998) mukaan teknologian ja käsityön käsitteet voidaan etymologisin perustein ymmärtää useammalla eri tavalla. Tällöin asiayhteydestä on pääteltävissä, miten kyseinen tulkinta on tehty. Tieteellisessä tekstissä käsitteitä on täsmennettävä. Käsityöllä tarkoitetaan lähinnä taitavaa ja taiteellista käsityövälineiden käyttöä. Teknologialla taas tarkoitetaan käsityöstä johdetun tekniikan taustalla olevien ja siihen lisättyjen tieteellisten teorioiden sekä niihin vaikuttavien toimintojen ja järjestelmien ymmärtämistä. Oleellista on, että teknologia käsitteessä painottuu tieteellinen tieto, ajattelu ja ymmärrys. (Parikka 1998, 39-40.) Teknologia käsitteen etymologista kehittymistä voidaan havainnollistaa seuraavan kuvion (Kuvio 1.) avulla.

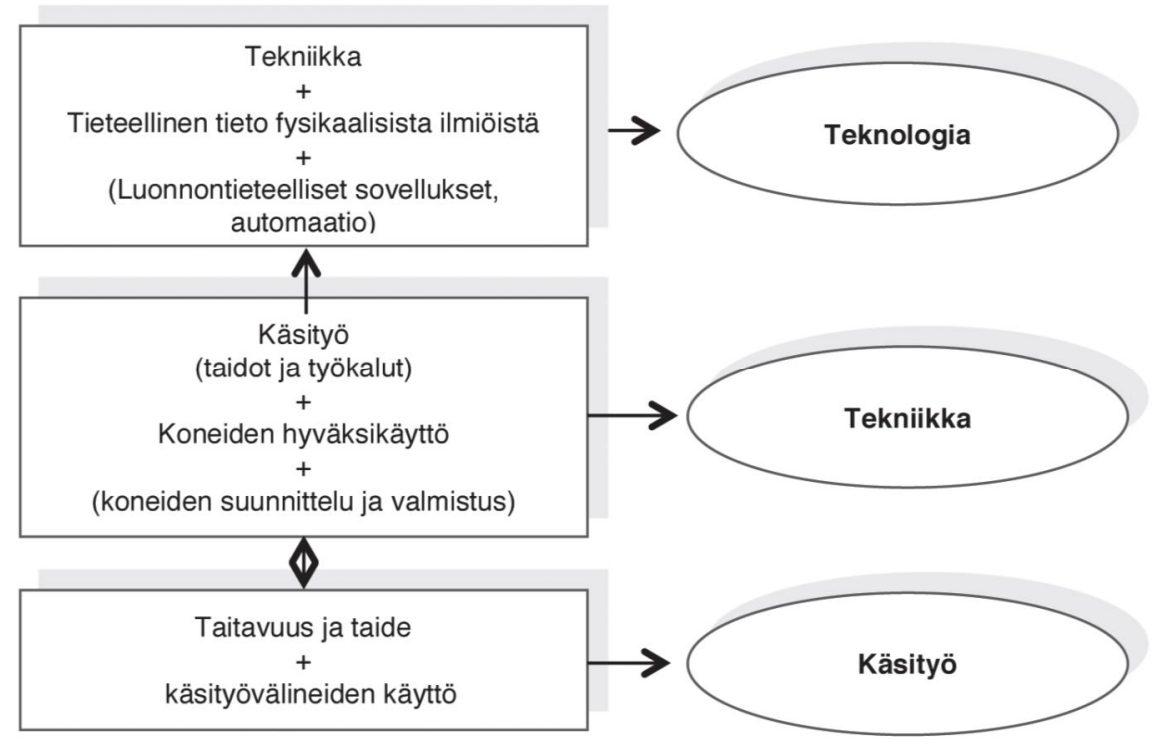

Kuvio 1. Teknologia käsitteen etymologinen kehitys (Parikka, 1998, 40)

Teknologiakasvatukseen liittyvänä käsitteenä STEM (Science, Technology, Engineering ja Mathematics) on vakiintunut sateenvarjokä- 
site, jolla tarkoitetaan tieteen ja teknologian alaan kuuluvien aiheiden opetusta. Kansainvälisissä tutkimuksissa on yhä enemmän tarkasteltu tyttöjen ja poikien asenteita ja käsityksiä näitä niin sanottuja STEM -aineita kohtaan. Sukupuolten välillä on todettu olevan selviä eroja liittyen oppilaiden minä-pystyvyyden tunteeseen ja kiinnostuneisuuteen aiheita kohtaan. Tutkimusten mukaan tytöt kokevat osaamisensa heikommaksi kuin pojat, eivätkä he ole poikien tavoin yhtä kiinnostuneita luonnontieteellisistä ja teknologisista oppiaineista (Ardies ym. 2013, de Vries 2005, de Weerd \& Rommes 2012, Endepohls-Ulpe ym. 2012). Myös kotimaisten tutkimusten perusteella on todettu, että pojat asennoituvat tyttöjä myönteisemmin matematiikan opiskeluun, vaikka tyttöjen asennoituminen kouluopiskelua kohtaan on yleisesti myönteisempää kuin poikien (Jakku-Sihvonen \& Komulainen 2004, Mattila 2005). Jakku-Sihvosen (2013) mukaan tyttöjen käsitykset myös omasta osaamisestaan sekä matematiikan että fysiikan oppiaineissa ovat melko kielteisiä, kun taas poikien vastaavat käsitykset ovat selvästi myönteisempiä ja poikien mielestä he osaavat fysiikkaa kohtuullisen hyvin. Lisäksi pojat pitävät fysiikkaa hyödyllisenä oppiaineena, kun taas tyttöjen mielestä fysiikka on vain jossain määrin hyödyllistä. (JakkuSihvonen 2013.)

Boser ym. (1998) mukaan oppilaiden asenteissa tapahtuvaa muutosta on harvoin tutkittu siten, että on seurattu erilaisten teknologiakasvatukseen liittyvien lähestymistapojen vaikutuksia pitkittäistutkimuksena. Yleinen oletus on, että sellaiset oppilaat, joilla on myönteisiä kokemuksia teknologiakasvatuksesta, omaksuvat muita myönteisemmän asenteen ja näin ollen myös kiinnostuvat alan opiskelusta muita enemmän ja jatkavat myöhemmin teknologiselle alalle (Popham 1994). Osallistuminen teknologiakasvatuksen opetukseen ei kuitenkaan merkittävästi muuttanut oppilaiden asenteita teknologiaa kohtaan. Kokeilussa, jossa opetuksen sisällöt vaihtelivat perinteisestä käsityöstä (Industrial arts) erityisiin teknologiakasvatuksen lähestymistapoihin, kuten kierrätykseen, kulkuneuvoihin, kuljetukseen ja ongelmaratkaisuun, vain perinteisellä käsityöllä oli myönteinen vaikutus oppilaiden teknologia-asenteisiin. Havaittiin, että tytöt pitivät teknologian ymmärtämistä yhtä mahdollisena sekä tytöille että pojille, mutta samalla tytöt ajattelivat, että teknologian ymmärtäminen ja sen käyttö on vaikeampaa kuin poikien mielestä. Mahdollisesti opittujen yhteiskunnallisten normien ylittäminen on suuri haaste, eikä yhdeksän viikon osallistuminen teknologiakasvatuksen eri ohjelmiin muuttanut näitä käsityksiä. (Boser ym. 1998.)

Kulttuurisia eroja esiintyy eri puolilla maailmaa, eikä tämän vuoksi kaikkia tuloksia voida yleistää. Van Rensburg ym. (1999) mukaan EteläAfrikassa ei löytynyt merkittäviä eroja sukupuolten välillä ja tytöiltä voidaan jatkossa odottaa entistä myönteisempää kehitystä. Pojat saattavat yhdistää teknologiset ammatit edelleen tehdastyöhön. Lisäksi akateeminen opiskelu ei ole pojilla yhtä suuressa arvossa kuin tytöillä. Ongelman ratkaisun tulisi tapahtua ruohonjuuritasolla siten, että resurssit ja käytössä olevat materiaalit huomioidaan opetussuunnitelman laadinnassa. Edelleen myös laadullisia tutkimusmenetelmiä, kuten esimerkiksi etnografista lähestymistapaa, tulisi hyödyntää asenteiden tutkimuksessa entistä enemmän. (Van Rensburg ym. 1999.) 
Käsityön kansallinen oppimistulosarviointi (2010) antoi uutta tietoa oppiaineesta. Pojat suhtautuivat oppiaineeseen tyttöjä myönteisemmin ja tietyillä maantieteellisillä alueilla poikien oppimistulokset olivat parempia kuin tyttöjen (Hilmola 2011). Tulos oli koulutuspoliittisesti mielenkiintoinen, koska aiempien eri oppiaineiden arviointitulosten perusteella tyttöjen asennoituminen opiskelua kohtaan oli todettu olevan myönteisempää kuin poikien ja tytöt yleensä olivat menestyneet eri oppiaineissa paremmin kuin pojat (Jakku-Sihvonen \& Komulainen 2004). Tällainen asetelma antoi aihetta tutkia käsityön oppiainetta tarkemmin opetussuunnitelmaan liittyvien lähtökohtien kontekstissa. Tässä artikkelissa tarkastellaan oppilaiden asenteita ja käsityksiä, jotka liittyvät käsityön oppiaineeseen. Lisäksi tässä artikkelissa tarkastellaan käsityön pakollisen oppimäärän jälkeiseen valinnaiseen opetukseen hakeutumista. Koulutukseen liittyvien tasa-arvoindikaattoreiden (ks. Metsämuuronen 2009) mukaisesti tarkastelu tapahtuu oppilaan sukupuolen, demograafisten taustatietojen ja sekä opettamiseen liittyvien että oppilaan yleistä osaamisen tasoa eri oppiaineissa kuvaavien taustatekijöiden kontekstissa. Kouluun ja oppimiseen liittyvien asenteiden ja käsitysten tutkiminen on aina ajankohtainen ja perusteltu tutkimusaihe, koska asenteilla on todettu olevan yhteyttä saavutettuihin oppimistuloksiin (Kärnä \& Rautopuro 2013). Perinteisen asennetutkimuksen peruspiirteenä on ollut oletus, että ihmisellä on yksilöllinen asenne tietyn kohteen arvottamiseen, joka saadaan mitattua sopivalla testillä tai mittarilla eli asenteella tarkoitetaan psykologista tendenssiä, joka ilmaistaan, kun jotain kokonaisuutta arvioidaan myönteisesti tai kielteisesti (Matikainen 2006, Eagly \& Chaiken 1993, Räty 1983). Voidaan ajatella, että asenteen kohde on jokin konkreettinen ja helposti rajattava, mutta yhtä hyvin se voi olla jokin abstrakti (McGuire 1985). Tässä artikkelissa asenteilla ja käsityksillä tarkoitetaan oppilaan myönteistä tai kielteistä suhtautumista käsityön oppiaineessa osaamiseen, oppiaineesta koettuun hyötyyn ja oppiaineen kiinnostavuuteen.

Perusopetuksen päättövaiheessa olevien tyttöjen ja poikien käsitykset liittyen käsityön oppiaineessa osaamiseen sekä oppiaineen hyödyllisyyteen ja kiinnostavuuteen ovat hyvin myönteisiä (Hilmola 2011, JakkuSihvonen 2013, Virtanen ym. 2015). Sukupuolten välillä on kuitenkin eroja poikien hyväksi ja poikien mielestä käsityö on jopa kiinnostavin oppiaine koulussa (Jakku-Sihvonen 2013, Hilmola 2011). Lisäksi pojat ovat neljä kertaa kiinnostuneempia tieteen ja tekniikan ammattiurista kuin tytöt (Vettenranta ym. 2016). Kansainvälisesti tarkasteltuna ilmiö on ollut samansuuntainen jo pitkään (Allsop 1986, Grant \& Harding 1987, Johnsson \& Murphy 1986, Streumer 1988). Myös viimeaikaisessa tutkimuksessa Eestissä, Islannissa ja Suomessa poikien on todettu olevan kiinnostuneita tekniikasta ja siihen liittyvistä ilmiöistä selvästi tyttöjä enemmän (Autio 2015). Tutkimuksissa on osoitettu, että pojat ovat tyttöjä itsevarmempia toimijoita ja että poikien kiinnostus teknologiaan liittyviin aiheisiin kasvaa kouluaikaisten opintojen myötä (Ardies ym. 2015, Virtanen ym. 2015). Sosiaalisella vuorovaikutuksella ja kannustuksella puolestaan näyttäisi olevan tärkeä rooli liittyen tyttöjen käsityön ja teknologian motivaatioon ja minä-pystyvyyteen, sillä tytöt kokevat tarvitsevansa kannustusta ja ohjausta erityisesti opettajiltaan ja he pelkäävät poikia enemmän tekevänsä jotain väärin (Virtanen ym. 2015). 


\section{Tutkimusaineisto ja menetelmät}

Tutkimusaineisto on kerätty lukuvuoden 2013-2014 aikana perusopetuksen seitsemännen luokan oppilailta. Tiedot kerättiin 59 peruskoulusta satunnaisotannalla siten, että yksittäisen koulun osallistuminen tutkimukseen perustui koulussa toimivien käsityönopettajien vapaaehtoisuuteen. Käsityönopettajia kutsuttiin tutkimukseen yhteistyöopettajiksi heitä edustavien opettajajärjestöjen (TAO ry ja TOL ry) avustuksella. Oppilaiden valikoituminen otokseen perustui heidän huoltajiensa antamaan suostumukseen. Otos on valtakunnallinen ja edustaa erilaisia kuntaryhmätyyppejä ja entisen läänijaon mukaisia suuralueita. Tutkimukseen osallistui yhteensä 982 seitsemäsluokkalaista, joista tyttöjen osuus oli 532 ja poikien osuus 450. Perusjoukko käsitti marraskuussa 2013 yhteensä 58453 seitsemäsluokkalaista, joista tyttöjä oli 28246 ja poikia 30207 (Suomen virallinen tilasto). Otoksen edustavuus perusjoukosta on noin 1,7 prosenttia.

Tutkimusote edustaa määrällistä eli kvantitatiivista tutkimusta. Tutkimusaineisto kerättiin Survey -tyyppisellä e-lomakekyselyllä. Mittarina käytettiin Opetushallituksen kehittelemää sovellusta valmiista FennemanShermannin (1978) asennetestistä, joka on laadittu alkuperäisen mittarin pohjalta pienin muutoksin siten, että se soveltuu käytettäväksi eri oppiaineiden yhteydessä. Opetushallitus ja myöhemmin Kansallinen koulutuksen arviointikeskus on käyttänyt asennetestiä kaikissa valtakunnallisissa oppimistulosten seuranta-arvioinneissa vuodesta 1998 alkaen. Nykymuotoinen sovellus asennetestistä on vuodelta 2001 ja sen avulla on tarkoitus selvittää oppilaiden ajankohtaisia asenteita ja käsityksiä yksittäisestä oppiaineesta kolmella ulottuvuudella: oppiaineessa osaaminen, oppiaineen hyödyllisyys ja oppiaineen kiinnostavuus. Jokaista ulottuvuutta mitataan viidellä yksittäisellä väittämällä niin, että ulottuvuuksiin liittyvät viisitoista väittämää sisältävät sekä myönteisiä että kielteisiä lauseita ja ne esitetään satunnaisessa järjestyksessä. Mittarin kysymyspatteri on Likert tyyppinen ja oppilaat vastaavat väittämiin asteikolla täysin eri mieltä - jonkin verran eri mieltä - kantani on epävarma tai minulla ei ole selvää käsitystä - jonkin verran samaa mieltä - täysin samaa mieltä. (ks. Metsämuuronen 2009, 20-21.) Tulosten yhteydessä asennetestin väittämät esitetään alkuperäisessä järjestyksessä siten, kuin ne on vastaajille mittaustilanteissa esitetty. (Kuvio 2). Lisäksi artikkelissa tarkastellaan oppilaiden käsityksiä käsityön valinnaiseen opetukseen hakeutumisesta eli käsityksiä mahdollisesta valintapäätöksestä tai oppiaineeseen liittyvistä aikomuksista. Oppilailta tiedusteltiin, että haluavatko he valita käsityötä myös valinnaiseksi oppiaineeksi joko pelkästään kahdeksannelle tai sekä kahdeksannelle että yhdeksännelle luokalle. Molempiin kysymyksiin vastausvaihtoehtoina olivat kyllä - mahdollisesti - ei. Tässä artikkelissa pelkästään kahdeksannelle luokalle ajoittuvasta käsityön valinnaisainevalinnasta käytetään nimitystä käsityön lyhyt valinta ja sekä kahdeksannelle että yhdeksännelle luokalle ajoittuvasta valinnasta käytetään nimitystä käsityön pitkä valinta.

Tutkimuksen taustamuuttujina käytettiin demografisia taustatekijöitä, joita yleensä käytetään kansallisissa oppimistulosten seuranta-arvioinneissa koulutuksen tasa-arvoindikaattoreina. Näitä ovat: oppilaan suku- 
puoli, kuntaryhmätyyppi ja suuraluetieto. Lisäksi taustamuuttujina käytetään käsityön opetuksen paikallisesti vaihtelevaa järjestämistapaa ja sekä käsityön, äidinkielen ja kirjallisuuden että matematiikan kuudennen luokan todistusarvosanoja. Käsityön opetuksen järjestämistapa kuvaa opettamiseen liittyviä tekijöitä ja eri oppiaineiden todistusarvosanat kuvaavat oppilaan yleistä osaamisen tasoa eri oppiaineissa. Käytetyt taustamuuttujat ovat osa laajempaa taustatekijöiden kokonaisuutta, jonka tarkoitus on auttaa löytämään ilmiöitä selittäviä tekijöitä, kuten selittää vaihtelua asenteissa ja käsityksissä (ks. Metsämuuronen 2009, 40-44). Taustamuuttujina käytettävät tiedot on kerätty tilastokeskuksen tietokannoista, käsityönopettajilta ja oppilaiden huoltajilta.

Asennemittarilla saatuja kolmen asenneulottuvuuden väittämäkohtaisia vastauksia kuvataan sukupuolten mukaisten keskiarvotasojen avulla. Kolmesta asenneulottuvuudesta muodostettujen summamuuttujien vaihtelua eri vastaajaryhmien välillä vertaillaan Mann-Whitneyn U-testin ja Kruskal-Wallisin Khiin neliötestin avulla. Muuttujien välisiä riippumattomuussuhteita tarkastellaan käyttämällä ristiintaulukointia ja Pearsonin Khiin neliötestiä. Koska aineisto on jossain määrin vino myönteisten vastausten suuntaisesti, analyysimenetelminä käytetään parametrittomia testimenetelmiä (ks. Metsämuuronen 2003). Lisäksi muuttujien välisten yhteyksien selvittämiseen käytetään lineaarista regressioanalyysia (askeltava menetelmä), joka joustavana perusmenetelmänä soveltuu käytettäväksi, koska menetelmän käyttöön liittyvät oletukset ja rajoitukset (ks. Metsämuuronen 2003, 580-581) eivät ole tässä aineistossa esteenä menetelmän käytölle.

Mittarin toistettavuutta eli reliabiliteettia ilmaiseva Cronbachin $\alpha$ kerroin oli 0,919 (käsitys oppiaineessa osaamisesta 0,757, käsitys oppiaineen hyödyllisyydestä 0,859 ja käsitys oppiaineen kiinnostavuudesta 0,895). Eri oppiaineiden kansallisten oppimistulosarviointien yhteydessä $\alpha$-kerroin on ollut säännönmukaisesti yli 0,900 ja asenneulottuvuuskohtaiset $\alpha$-kertoimet ovat vaihdelleet välillä 0,770-0,900 (ks. Metsämuuronen 2009, 37). Tältä osin myös tässä tutkimuksessa mittarin erottelukykyä voidaan pitää hyvänä ja saatua tulosta uskottavana. Validiteetin osalta luotettavuus on suurelta osin sopimusvarainen, mutta määrällisessä tutkimuksessa suuri otoskoko jo sinällään takaa tietynlaisen luotettavuuden eli kyse on otannan tekemiseen liittyvästä pohdinnasta. Tässä tutkimusaineistossa sisäisen validiteetin (reliabiliteetti) suhteen ei liene ongelmaa. Tarkasteltaessa ulkoista validiteettia voidaan todeta, että tutkimusaineisto on maantieteellisesti varsin kattava, mutta otoskoon arviointi on aina tilannekohtaista. Lähes tuhannen oppilaan $(\mathrm{N}=982)$ valtakunnallinen otos ei kuitenkaan liene ongelma tutkimuksen validiteetille, vaan päinvastoin. Mainittakoon, että opetushallitus on tuottanut valtakunnallisesti yleistettävää arviointitietoa otoskoon ollessa 5000-6000 oppilasta. (ks. Metsämuuronen 2003, 86, Metsämuuronen 2009, 13, Erätuuli ym. 1994, 100). Lisäksi tässä esitetyt tulokset eivät ole ristiriidassa aiempien tutkimustulosten kanssa ja kansainvälisesti tarkasteltuna ilmiö on ollut samansuuntainen jo pitkään (Allsop 1986, Grant \& Harding 1987, Johnsson \& Murphy 1986, Streumer 1988, de Vries 2005, Ardies ym. 2013, de Weerd \& Rommes 2012, Endepohls-Ulpe ym. 2012). 


\section{Seitsemäsluokkalaisten asenteita ja käsityksiä käsi- työn oppiaineessa}

Seuraavaksi tarkastellaan perusopetuksen seitsemäsluokkalaisten oppilaiden käsityön oppiaineeseen liittyviä asenteita ja käsityksiä siten, että aluksi huomio kohdistuu tutkimuksen alaongelmien tarkasteluun. Lopuksi haetaan vastausta tutkimuksen pääongelmaan: Missä määrin tyttöjen ja poikien käsityön oppiaineeseen liittyvät asenteet ja käsitykset eroavat toisistaan? Ensiksi tyttöjen ja poikien väittämäkohtaisia keskiarvotasoja kuvaillaan Fenneman-Shermannin (1978) asennetestillä saatujen tulosten perusteella (Kuvio 2). Tämän jälkeen tarkastelu kohdistuu kolmen asenneulottuvuuden keskiarvotasoihin siten, että niiden summamuuttujissa havaittua vaihtelua vertaillaan eri vastaajaryhmien välillä (Taulukko 1). Lisäksi tässä yhteydessä halutaan selvittää asenneulottuvuuksien yhteyttä tyttöjen ja poikien käsityksiin liittyen käsityön valinnaiseen opetukseen hakeutumiseen (Taulukko 2). Lopuksi halutaan tietää, missä määrin tyttöjen ja poikien käsitykset käsityön valinnaiseen opetukseen hakeutumisesta joko lyhyenä tai pitkänä valintana ovat riippuvaisia paikallisesti vaihtelevista käsityön opetuksen erilaisista toteuttamiskäytännöistä (Taulukko 3).

\section{Tyttöjen ja poikien väittämäkohtaiset keskiarvot asennetestissä}

Ensimmäinen asenneulottuvuus kuvaa oppilaiden käsityksiä oppiaineessa osaamisesta (väittämät 01, 03, 10, 11 ja 12). Oppilaiden vastaukset osoittavat, että perusopetuksen seitsemäsluokkalaiset oppilaat pitävät käsityötä suhteellisen helppona oppiaineena. Lisäksi oppilaiden vastauksista selviää, että heidän ei ole ollut mahdotonta päästä hyviin tuloksiin tässä oppiaineessa. Aivan yhtä myönteisiä oppilaiden vastaukset eivät ole sen suhteen, että käsityöhön liittyvät asiat eivät olisi olleet vaikeita. Keskiarvotason perusteella 84 prosentissa oppilaiden (tytöt $83 \%$, pojat $86 \%$ ) vastauksista tuli näkyville myönteisesti painottunut käsitys omasta osaamisesta käsityön oppiaineessa. (Kuvio 2.)

Toinen asenneulottuvuus kuvaa oppilaiden käsityksiä oppiaineen hyödyllisyydestä (väittämät 02, 07, 09, 13 ja 15). Oppilaiden vastaukset osoittavat, että tytöt ja pojat pitävät käsityön osaamista tärkeänä. Kuitenkin pojat uskovat tarvitsevansa käsityön taitoja ja tietoja tulevissa opinnoissaan ja työelämässä selvästi enemmän kuin tytöt. Keskiarvotason perusteella 73 prosentissa oppilaiden (tytöt $69 \%$, pojat $77 \%$ ) vastauksista tuli näkyville myönteisesti painottunut käsitys käsityön oppiaineen hyödyllisyydestä. (Kuvio 2.)

Kolmas asenneulottuvuus kuvaa oppilaiden käsityksiä oppiaineen kiinnostavuudesta (väittämät 04, 05, 06, 08 ja 14). Oppilaiden vastaukset osoittavat, että kaikissa viidessä väittämässä poikien käsitykset oppiaineen kiinnostavuudesta olivat myönteisempiä kuin tyttöjen. Kuitenkin kaikki oppilaat, mutta erityisesti pojat, kokevat vahvasti sekä pitävänsä käsityön oppitunneista että opiskelevansa mielellään käsityötä. Lisäksi oppilaat, erityisesti pojat, eivät pitäneet käsityötä ikävystyttävänä oppiaineena. Keskiarvotason perusteella 79 prosentissa oppilaiden (tytöt $76 \%$, pojat $83 \%$ ) vastauksista tuli näkyville myönteisesti painottunut käsitys käsityön oppiaineen kiinnostavuudesta. (Kuvio 2.) 
Ainedidaktiikka 1(1) (2017)

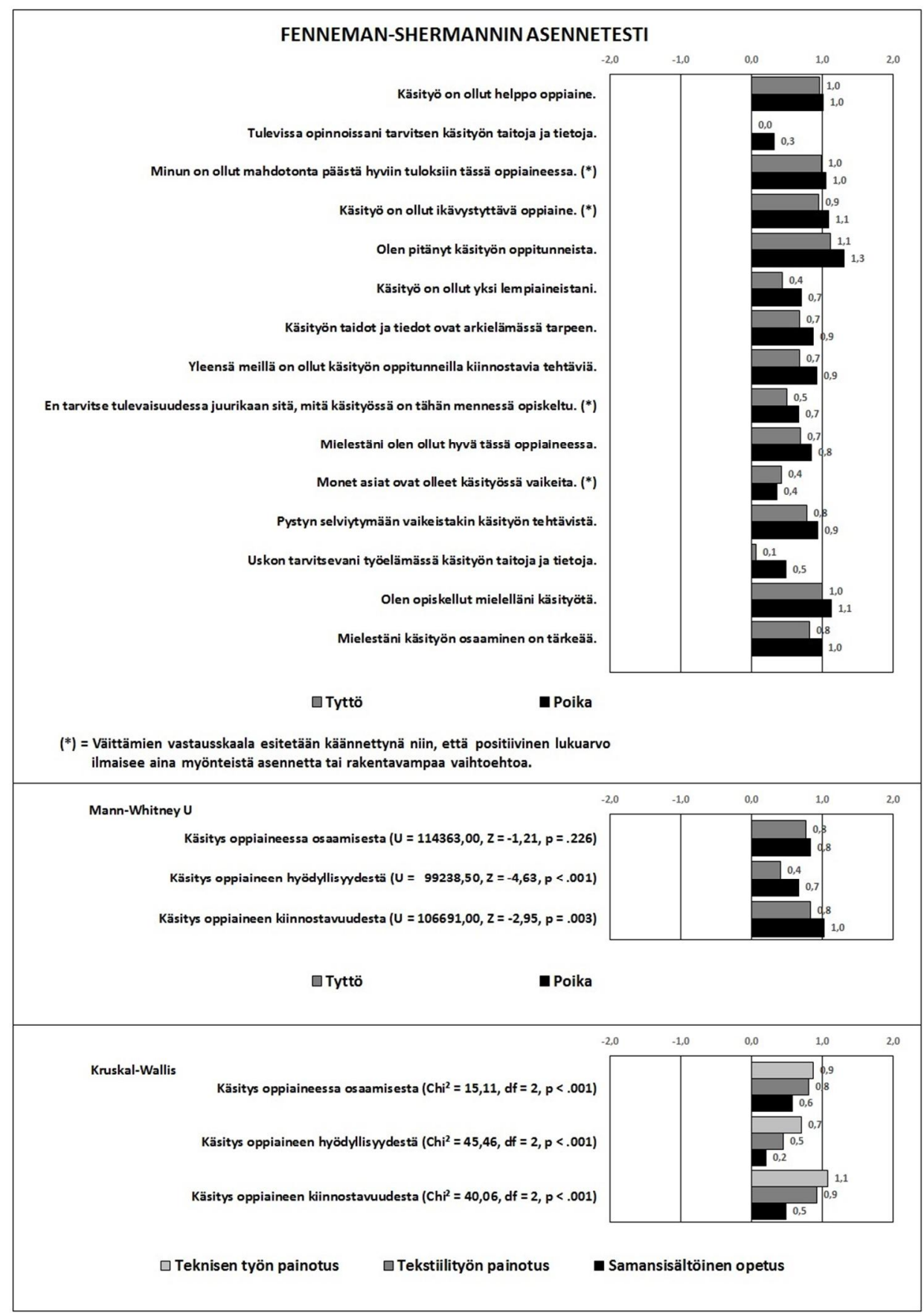

Kuvio 2. Seitsemäsluokkalaisten oppilaiden asenteita ja käsityksiä käsityön oppiaineesta.

Tarkasteltaessa asenneulottuvuuksia kuvaavien summamuuttujien keskiarvotasoissa ilmenevää vaihtelua oppilaan sukupuolen mukaan, voidaan havaita, että poikien käsitykset käsityön oppiaineen hyödyllisyydestä ja kiinnostavuudesta ovat selvästi myönteisempiä kuin saman ikäisillä tytöillä. Lisäksi tarkasteltaessa vaihtelua käsityön opetuksen paikallisesti vaihtelevien järjestämistapojen mukaan, voidaan havaita, että teknisen työn sisältöjen painotettuun opetukseen osallistuneiden oppilaiden käsitykset ovat kaikilla asenneulottuvuuksilla selvästi myönteisempiä kuin muiden oppilaiden vastaavat käsitykset ja vastaavasti saman sisältöiseen käsityön opetukseen osallistuneiden oppilaiden käsitykset ovat huomattavasti vähemmän myönteisiä kuin muilla oppilailla. Havaitut erot ovat tilastollisesti merkitseviä tai tilastollisesti erittäin merkitseviä. (Kuvio 2.) 
Ainedidaktiikka 1(1) (2017)

Asenteiden tarkastelu toi kaiken kaikkiaan esille ilmeisiä eroja tyttöjen ja poikien käsityksissä. Tytöt ja pojat olivat eri mieltä varsinkin oppiaineen hyödyllisyydestä: erot olivat suurimmillaan väittämien 2 ja 13 kohdalla. Tytöistä 27 prosenttia ja pojista 42 prosenttia oli täysin samaa mieltä tai samaa mieltä kysyttäessä sitä, tarvitseeko oppilas tulevissa opinnoissaan käsityön taitoja ja tietoja. Tytöistä 33 prosenttia ja pojista 53 prosenttia oli täysin samaa mieltä tai samaa mieltä kysyttäessä, uskooko oppilas tarvitsevansa työelämässä käsityön taitoja ja tietoja. (Kuvio 2.)

\section{Kolmen asenneulottuvuuden keskiarvotasojen vaihtelu eri vastaaja- ryhmien välillä}

Tyttöjen kohdalla myönteinen käsitys käsityön kiinnostavuudesta painottuu maaseudun tyttöjen vastauksissa enemmän kuin muilla tytöillä. Tytöt, jotka ovat saaneet käsityössä ja matematiikassa vähintään kiitettäviä todistusarvosanoja kuudennella luokalla, suhtautuvat omaan käsityön osaamiseensa muita tyttöjä myönteisemmin ja pitävät käsityötä enemmän hyödyllisenä ja kiinnostavana oppiaineena kuin muut tytöt. Lisäksi tytöt, jotka ovat saaneet äidinkielessä ja kirjallisuudessa vähintään kiitettäviä todistusarvosanoja, suhtautuvat omaan käsityön osaamiseensa muita tyttöjä myönteisemmin. Tytöt, jotka ovat saaneet käsityössä tyydyttäviä tai hyviä todistusarvosanoja, pitävät käsityötä vähemmän hyödyllisenä oppiaineena kuin muut tytöt. Havaitut erot ovat tilastollisesti merkitseviä tai tilastollisesti erittäin merkitseviä. (Taulukko 1.)

Poikien kohdalla myönteinen käsitys käsityön osaamisesta, hyödyllisyydestä ja kiinnostavuudesta painottuu maaseudun ja Oulun alueen poikien vastauksissa enemmän kuin muilla pojilla. Pojat, jotka ovat saaneet käsityössä ja matematiikassa vähintään kiitettäviä todistusarvosanoja kuudennella luokalla, suhtautuvat omaan käsityön osaamiseensa muita poikia myönteisemmin. Lisäksi sellaiset pojat, jotka ovat saaneet käsityössä vähintään kiitettäviä ja äidinkielessä ja kirjallisuudessa korkeintaan kohtalaisia todistusarvosanoja, pitävät käsityötä enemmän hyödyllisenä ja kiinnostavana oppiaineena kuin muut pojat. Lapin alueen pojat pitävät omaa käsityön osaamista keskimäärin heikompana ja käsityötä vähemmän kiinnostavana oppiaineena kuin muut pojat. Havaitut erot ovat tilastollisesti merkitseviä tai tilastollisesti erittäin merkitseviä. (Taulukko 1.)

Taulukko 1. Vastaajaryhmien välisiä eroja asenteissa ja käsityksissä 
Ainedidaktiikka 1(1) (2017)

Riippumattomien ryhmien keskiarvotasojen välistä vaihtelua asenteissa ja käsityksissä

\begin{tabular}{|c|c|c|c|c|c|c|}
\hline \multirow[t]{2}{*}{ Oppilaan käsitys } & \multicolumn{2}{|c|}{$\begin{array}{l}\text { oppiaineessa } \\
\text { osaamisesta }\end{array}$} & \multicolumn{2}{|c|}{$\begin{array}{c}\text { oppiaineen } \\
\text { hyödyllisyydestä }\end{array}$} & \multicolumn{2}{|c|}{$\begin{array}{c}\text { oppiaineen } \\
\text { kiinnostavuudesta }\end{array}$} \\
\hline & tytöt & pojat & tytöt & pojat & tytöt & pojat \\
\hline \multicolumn{7}{|l|}{ Kuntaryhmätyyppi } \\
\hline Kaupunki $(n=594)$ & 0,8 & 0,8 & 0,4 & 0,5 & 0,8 & 0,9 \\
\hline Taajama $(n=245)$ & 0,7 & 0,9 & 0,4 & 0,9 & 0,8 & 1,0 \\
\hline Maaseutu $(n=143)$ & 1,0 & 1,0 & 0,6 & 1,0 & 1,1 & 1,5 \\
\hline Kruskal-Wallis Chi ${ }^{2}$ & 5,9 & 8,4 & 3,5 & 36,4 & 8,6 & 21,3 \\
\hline df & 2 & 2 & 2 & 2 & 2 & 2 \\
\hline $\mathrm{p}$ & $=.054$ & $=.015$ & $=.171$ & $<.001$ & $=.014$ & $<.001$ \\
\hline \multicolumn{7}{|l|}{ Suuralue } \\
\hline Etelä-Suomi $(n=391)$ & 0,7 & 0,8 & 0,4 & 0,5 & 0,8 & 0,9 \\
\hline Länsi-Suomi ( $\mathrm{n}=267$ ) & 0,7 & 0,8 & 0,4 & 0,6 & 0,7 & 1,0 \\
\hline Itä-Suomi (n = 71 ) & 0,9 & 0,9 & 0,4 & 0,9 & 0,8 & 1,1 \\
\hline Oulu $(n=211)$ & 0,9 & 1,0 & 0,6 & 1,1 & 1,0 & 1,4 \\
\hline Lappi $(n=42)$ & 0,9 & 0,2 & 0,5 & $-0,1$ & 1,0 & 0,4 \\
\hline Kruskal-Wallis $\mathrm{Chi}^{2}$ & 7,2 & 12,7 & 5,3 & 46,4 & 8,6 & 29,2 \\
\hline df & 4 & 4 & 4 & 4 & 4 & 4 \\
\hline $\mathrm{p}$ & $=.125$ & $=.013$ & $=.258$ & $<.001$ & $=.071$ & $<.001$ \\
\hline \multicolumn{7}{|l|}{ Käsityön 6. luokan todistusarvosana } \\
\hline Kiitettävä-Erinomainen; 9-10 $(n=428)$ & 1,0 & 1,2 & 0,6 & 0,9 & 1,1 & 1,4 \\
\hline Tyydyttävä-Hyvä; 7-8 (n= 546) & 0,5 & 0,7 & 0,2 & 0,5 & 0,5 & 0,9 \\
\hline Heikko-Kohtalainen; 4-6 $(n=8)$ & 0,5 & 0,3 & 0,5 & 1,1 & 1,9 & 1,0 \\
\hline Kruskal-Wallis Chi² & 87,6 & 60,1 & 32,5 & 22,3 & 55,9 & 33,7 \\
\hline df & 2 & 2 & 2 & 2 & 2 & 2 \\
\hline $\mathrm{p}$ & $<.001$ & $<.001$ & $<.001$ & $<.001$ & $<.001$ & $<.001$ \\
\hline \multicolumn{7}{|l|}{ Äidinkielen ja kirjallisuuden 6. luokan todistusarvosana } \\
\hline Kiitettävä-Erinomainen; 9-10 $(n=465)$ & 0,9 & 0,9 & 0,4 & 0,5 & 0,9 & 0,9 \\
\hline Tyydyttävä-Hyvä; 7-8 (n= 487) & 0,6 & 0,8 & 0,4 & 0,7 & 0,8 & 1,1 \\
\hline Heikko-Kohtalainen; 4-6 $(n=30)$ & 0,5 & 0,9 & 0,2 & 0,9 & 0,5 & 1,2 \\
\hline Kruskal-Wallis $\mathrm{Chi}^{2}$ & 11,2 & 1,3 & 1,0 & 9,9 & 0,6 & 7,7 \\
\hline df & 2 & 2 & 2 & 2 & 2 & 2 \\
\hline $\mathrm{p}$ & $=.004$ & $=.518$ & $=.595$ & $=.007$ & $=.760$ & $=.021$ \\
\hline \multicolumn{7}{|l|}{ Matematiikan 6. luokan todistusarvosana } \\
\hline Kiitettävä-Erinomainen; 9-10 $(n=474)$ & 0,9 & 1,0 & 0,5 & 0,6 & 1,0 & 1,1 \\
\hline Tyydyttävä-Hyvä; 7-8 (n = 454) & 0,6 & 0,7 & 0,3 & 0,7 & 0,7 & 1,0 \\
\hline Heikko-Kohtalainen; 4-6 $(n=54)$ & 0,5 & 0,8 & 0,3 & 1,0 & 0,7 & 1,1 \\
\hline Kruskal-Wallis $\mathrm{Chi}^{2}$ & 29,0 & 11,1 & 10,5 & 2,7 & 8,4 & 0,0 \\
\hline df & 2 & 2 & 2 & 2 & 2 & 2 \\
\hline $\mathrm{p}$ & $<.001$ & $=.004$ & $=.005$ & $=.260$ & $=.015$ & $=.978$ \\
\hline
\end{tabular}

Tyttöjen ja poikien käsitykset käsityön valinnaiseen opetukseen hakeutumisesta joko lyhyenä tai pitkänä valintana

Seuraavaksi tarkastellaan oppilaiden oppiaineeseen liittyvien asenteiden ja käsitysten yhteyttä heidän käsityksiinsä käsityön valinnaiseen opetukseen hakeutumisesta. Regressioanalyysin perusteella voidaan havaita, että käsitykset oppiaineen hyödyllisyydestä ja kiinnostavuudesta selittävät 34 prosenttia (tytöt $34 \%$, pojat $33 \%$ ) oppiaineen lyhyeen valintaan ja 40 prosenttia (tytöt $39 \%$, pojat $39 \%$ ) oppiaineen pitkään valintaan liittyviä käsityksiä valintapäätöksistä. Selittävien muuttujien painokertoimet ( $\beta$ ) eroavat nollasta tilastollisesti merkitsevästi tai erittäin merkitsevästi. Käsitys oppiaineessa osaamisesta ei ole tilastollisessa mielessä luotettava selittäjä ( $p$ > .050) valinnaiseen opetukseen hakeutumiselle. (Taulukko 2.)

Taulukko 2. Asenteiden ja käsitysten yhteys valinnaiseen opetukseen hakeutumiseen 
Ainedidaktiikka 1(1) (2017)

Käsityön valintoja selittävät asenteet ja käsitykset

\begin{tabular}{|c|c|c|c|c|c|c|}
\hline & $\begin{array}{c}\text { Koko otos } \\
(\mathrm{N}=982)\end{array}$ & $\begin{array}{c}\text { Tytöt } \\
(n=532)\end{array}$ & $\begin{array}{c}\text { Pojat } \\
(n=450)\end{array}$ & $\begin{array}{c}\text { Koko otos } \\
(\mathrm{N}=982)\end{array}$ & $\begin{array}{c}\text { Tytöt } \\
(n=532)\end{array}$ & $\begin{array}{c}\text { Pojat } \\
(n=450)\end{array}$ \\
\hline Riippumattomat muuttujat & $\beta$ & $\beta$ & $\beta$ & $\beta$ & $\beta$ & $\beta$ \\
\hline Oppiaineen kiinnostavuus & $0,442^{1}$ & $0,448^{1}$ & $0,445^{1}$ & $0,454^{1}$ & $0,471^{1}$ & $0,447^{1}$ \\
\hline Oppiaineen hyödyllisyys & $0,186^{1}$ & $0,177^{1}$ & $0,166^{2}$ & $0,226^{1}$ & $0,195^{1}$ & $0,234^{1}$ \\
\hline \multirow[t]{2}{*}{ Oppiaineessa osaaminen } & - & - & - & - & - & - \\
\hline & $\downarrow$ & $\downarrow$ & $\downarrow$ & $\downarrow$ & $\downarrow$ & $\downarrow$ \\
\hline Riippuvat muuttujat & \multicolumn{3}{|c|}{ Käsityön lyhyt valinta (8. Ik) } & \multicolumn{3}{|c|}{ Käsityön pitkä valinta (8. ja 9. lk) } \\
\hline $\mathrm{R}^{2}$ & 0,342 & 0,341 & 0,325 & 0,397 & 0,394 & 0,386 \\
\hline & \multicolumn{4}{|c|}{ Beta-kertoimen ( $\beta$ ) poikkeavuus nollasta: } & ${ }^{1} p<.001$ & ${ }^{2} p=.002$ \\
\hline
\end{tabular}

Tyttöjen ja poikien käsityön valinnaiseen opetukseen hakeutumisen riippuvaisuus käsityön opetuksen erilaisista järjestämistavoista

Tarkasteltaessa oppilaiden käsityksiä valinnaiseen opetukseen hakeutumisesta joko lyhyenä tai pitkänä valintana voidaan havaita, että painotettuun tekstiilityön tai erityisesti painotettuun teknisen työn opetukseen seitsemännellä luokalla osallistuneet oppilaat hakeutuvat käsityön valinnaiseen opetukseen selvästi useammin kuin saman sisältöiseen käsityön opetukseen osallistuneet oppilaat. Lisäksi sellaiset oppilaat, jotka ovat varmoja, että eivät hakeudu käsityön valinnaiseen opetukseen, ovat muita useammin opiskelleet saman sisältöistä käsityötä. Oppilaiden käsitykset käsityön valinnaiseen opetukseen hakeutumisesta sekä lyhyenä että pitkänä valintana ovat riippuvaisia käsityön opetuksen paikallisesti vaihtelevista järjestämistavoista. Havaitut erot ovat tilastollisesti erittäin merkitseviä. (Taulukko 3.)

Tyttöjen kohdalla painotettuun tekstiilityön sisältöjen opetukseen osallistuminen seitsemännellä luokalla indikoi selvästi eniten ja painotettuun teknisen työn sisältöjen opetukseen osallistuminen selvästi vähiten käsityön sekä lyhyeen että pitkään valintaan hakeutumista. Vastaavasti poikien kohdalla painotettuun teknisen työn sisältöjen opetukseen osallistuminen indikoi selvästi eniten ja painotettuun tekstiilityön sisältöjen opetukseen osallistuminen selvästi vähiten käsityön sekä lyhyeen että pitkään valintaan hakeutumista. Sekä tyttöjen että poikien käsitykset käsityön valinnaiseen opetukseen hakeutumisesta joko lyhyenä tai pitkänä valintana ovat riippuvaisia käsityön opetuksen paikallisesti vaihtelevista järjestämistavoista. Havaitut erot ovat tilastollisesti merkitseviä. (Taulukko 3.)

Käsityön valinnaiseen opetukseen hakeutumisen tarkastelu toi esille ilmeisiä eroja tyttöjen ja poikien käsityksissä liittyen heidän valintapäätöksiin. Tytöistä 24 prosenttia ja pojista 37 prosenttia oli varma kannastaan, että valitsee käsityötä lyhyenä valintana. Vastaavasti 33 prosenttia tytöistä ja 22 prosenttia pojista ilmaisi kielteisen kannan käsityön lyhyeen valintaan osallistumisesta. Lisäksi tytöistä 19 prosenttia ja pojista 30 prosenttia oli varma, että valitsee käsityötä pitkänä valintana. Vastaavasti 38 prosenttia tytöistä ja 27 prosenttia pojista ilmaisi kielteisen kannan käsityön pitkään valintaan osallistumisesta. On kuitenkin huomattava, että epävarmojen eli valintapäätöstä vielä mahdollisesti pohtivien vastaajien osuudet ovat suhteellisen suuria. (Taulukko 3.) 
Ainedidaktiikka 1(1) (2017)

Taulukko 3. Käsityön valintojen riippuvaisuus opetuksen järjestämistavoista

\begin{tabular}{|c|c|c|c|c|c|c|}
\hline Käsityön opetuksen järjestämistapa & \multicolumn{3}{|c|}{ Käsityön lyhyt valinta (8. Ik) } & \multicolumn{3}{|c|}{ Käsityön pitkä valinta (8. ja 9. lk) } \\
\hline Koko otos $(\mathrm{N}=982)$ & $\begin{array}{c}\text { Kyllä } \\
(n=291)\end{array}$ & $\begin{array}{l}\text { Mahdollisesti } \\
\quad(n=414)\end{array}$ & $\begin{array}{c}\mathrm{Ei} \\
(\mathrm{n}=277)\end{array}$ & $\begin{array}{c}\text { Kyllä } \\
(n=233)\end{array}$ & $\begin{array}{l}\text { Mahdollisesti } \\
\quad(n=424)\end{array}$ & $\begin{array}{c}E \mathrm{E} \\
(\mathrm{n}=325)\end{array}$ \\
\hline Teknisen työn painotus $(n=431)$ & $38 \%$ & $37 \%$ & $25 \%$ & $30 \%$ & $41 \%$ & $29 \%$ \\
\hline Tekstiilityön painotus $(n=407)$ & $25 \%$ & $45 \%$ & $30 \%$ & $20 \%$ & $46 \%$ & $34 \%$ \\
\hline Samansisältöinen käsityö $(n=144)$ & $18 \%$ & $50 \%$ & $32 \%$ & $14 \%$ & $43 \%$ & $43 \%$ \\
\hline \multirow{2}{*}{ Odotusarvot $(\mathrm{N}=982)$} & $30 \%$ & $42 \%$ & $28 \%$ & $24 \%$ & $43 \%$ & $33 \%$ \\
\hline & \multicolumn{3}{|c|}{ Pearsonin $\mathrm{Chi}^{2}=26,1, \mathrm{df}=4, \mathrm{p}<.001$} & \multicolumn{3}{|c|}{ Pearsonin $\mathrm{Chi}^{2}=23,0, \mathrm{df}=4, \mathrm{p}<.001$} \\
\hline Tytöt $(n=532)$ & $\begin{array}{c}\text { Kyllä } \\
(n=125)\end{array}$ & $\begin{array}{l}\text { Mahdollisesti } \\
\quad(n=229)\end{array}$ & $\begin{array}{c}E i \\
(n=178)\end{array}$ & $\begin{array}{c}\text { Kyllä } \\
(n=100)\end{array}$ & $\begin{array}{l}\text { Mahdollisesti } \\
\quad(n=229)\end{array}$ & $\begin{array}{c}E i \\
(n=203)\end{array}$ \\
\hline Teknisen työn painotus $(n=63$ ) & $17 \%$ & $29 \%$ & $54 \%$ & $13 \%$ & $27 \%$ & $60 \%$ \\
\hline Tekstiilityön painotus $(n=402)$ & $25 \%$ & $45 \%$ & $30 \%$ & $21 \%$ & $46 \%$ & $33 \%$ \\
\hline Samansisältöinen käsityö $(n=67)$ & $18 \%$ & $45 \%$ & $37 \%$ & $13 \%$ & $42 \%$ & $45 \%$ \\
\hline \multirow[t]{2}{*}{ Odotusarvot $(n=532)$} & $24 \%$ & $43 \%$ & $33 \%$ & $19 \%$ & $43 \%$ & $38 \%$ \\
\hline & \multicolumn{3}{|c|}{ Pearsonin $\mathrm{Chi}^{2}=16,0, \mathrm{df}=4, \mathrm{p}=.003$} & \multicolumn{3}{|c|}{ Pearsonin $\mathrm{Chi}^{2}=18,6, \mathrm{df}=4, \mathrm{p}=.001$} \\
\hline Pojat $(n=450)$ & $\begin{array}{c}\text { Kyllä } \\
(n=166)\end{array}$ & $\begin{array}{l}\text { Mahdollisesti } \\
\quad(n=185)\end{array}$ & $\begin{array}{c}E i \\
(n=99)\end{array}$ & $\begin{array}{c}\text { Kyllä } \\
(n=133)\end{array}$ & $\begin{array}{l}\text { Mahdollisesti } \\
\quad(n=195)\end{array}$ & $\begin{array}{c}\mathrm{Ei} \\
(n=122)\end{array}$ \\
\hline Teknisen työn painotus $(n=368)$ & $41 \%$ & $38 \%$ & $21 \%$ & $33 \%$ & $43 \%$ & $24 \%$ \\
\hline Tekstillityön painotus $(n=5)$ & $20 \%$ & $40 \%$ & $40 \%$ & $0 \%$ & $60 \%$ & $40 \%$ \\
\hline Samansisältöinen käsityö $(n=77)$ & $18 \%$ & $55 \%$ & $27 \%$ & $14 \%$ & $44 \%$ & $42 \%$ \\
\hline \multirow[t]{2}{*}{ Odotusarvot $(n=450)$} & $37 \%$ & $41 \%$ & $22 \%$ & $30 \%$ & $43 \%$ & $27 \%$ \\
\hline & \multicolumn{3}{|c|}{ Pearsonin $\mathrm{Chi}^{2}=15,5, \mathrm{df}=4, \mathrm{p}=.004$} & \multicolumn{3}{|c|}{ Pearsonin $\mathrm{Chi}^{2}=17,1, \mathrm{df}=4, \mathrm{p}=.002$} \\
\hline
\end{tabular}

\section{Missä määrin tyttöjen ja poikien käsityöhön liittyvät asenteet eroa- vat toisistaan?}

Tulosten perusteella näyttää siltä, että seitsemäsluokkalaiset pojat pitävät käsityötä selkeästi enemmän hyödyllisenä ja kiinnostavana oppiaineena kuin saman ikäiset tytöt. Myönteiset asenteet ja käsitykset painottuivat $\mathrm{Ou}-$ lun alueen ja maaseudun poikien vastauksissa muita enemmän. Tyttöjen kohdalla maaseudun tytöt löysivät oppiaineesta keskimäärin enemmän kiinnostavia tekijöitä kuin muut tytöt. Samansuuntaiseen havaintoon päädyttiin myös vuonna 2010, jolloin Opetushallitus toteutti käsityön kansallisen oppimistulosarvioinnin perusopetuksen päättövaiheessa oleville oppilaille (vrt. Hilmola 2011). Nyt asenteita ja käsityksiä tarkasteltiin useampien taustamuuttujien mukaan ja käsityön opetuksen tulevaisuuden kannalta mielenkiintoisena havaintona nousee esiin seikka, että teknisen työn sisältöjen painotettuun opetukseen osallistuneiden oppilaiden vastauksissa erottuu selvästi muita myönteisempi ja vastaavasti saman sisältöisen käsityön opetukseen osallistuneiden oppilaiden vastauksissa muita vähemmän myönteinen suhtautuminen oppiaineessa osaamiseen sekä oppiaineen hyödyllisyyteen ja kiinnostavuuteen. Lisäksi painotettuun teknisen työn sisältöjen opetukseen osallistuneet oppilaat hakeutuvat selvästi muita useammin ja vastaavasti saman sisältöiseen käsityön opetukseen osallistuneet muita harvemmin käsityön valinnaiseen opetukseen. Sukupuolten mukaan tarkasteltuna painotettuun tekstiilityön sisältöjen opetukseen osallistuneet tytöt ja painotettuun teknisen työn sisältöjen opetukseen osallistuneet pojat hakeutuvat muita useammin käsityön valinnaiseen opetukseen (vrt. Autio 2013). Mainittakoon vielä, että tyttöjen kohdalla korkeat todistusarvosanat eri oppiaineissa ennakoivat muita myönteisempää suhtautumista käsityöhön. Poikien kohdalla korkeat todistusarvosanat käsityössä ja matematiikassa sekä alhaiset todistusarvosanat äidinkielessä ja kirjallisuudessa ennakoivat niin ikään muita myönteisempää suhtautumista käsityöhön. 


\section{Pohdinta}

Opetushallitus on normiohjannut käsityön opetuksen järjestämisen tulevaisuudessa siten, että pakollinen oppimäärä ja taide- ja taitoaineiden valinnainen oppimäärä toteutetaan yhteisenä käsityönä, jossa käytetään sekä teknisen työn että tekstiilityön työtapoja. Siis jatkossa käsityön opetusta voidaan järjestää johonkin syventävään osaamisalueeseen tai tiettyihin työtapoihin painotettuna vain perusopetuksen yhteisten valinnaisaineiden oppimäärän rajoissa (ks. Opetushallitus 2015).

Tulosten pohjalta herää monia kysymyksiä. Kun tulevaisuudessa käsityön opetus toteutetaan pelkästään kaikille yhteisenä käsityönä, niin koetaanko oppiaineen osaaminen, hyödyllisyys ja kiinnostavuus selvästi vähemmän myönteisenä kuin aikaisemmin? Tarkoittaako tulos samalla myös sitä, että oppiaineen valinnaiseen opetukseen hakeudutaan huomattavasti harvemmin kuin vielä tällä hetkellä? Edelleen voidaan kysyä, että opetetaanko käsityön pakollisen oppimäärän lisäksi tarjottavaa valinnaista oppimäärää tulevaisuudessa yhä harvemmalla oppilasjoukolle? Vai onko peräti valinnaisen oppimäärän opetuksen toteutuminen vaarassa, jos oppilaat eivät valitse käsityötä valinnaisaineeksi. Johtaako tämä siihen, että käsityöstä kehittyy pelkästään alaluokkien oppiaine ja seuraavan opetussuunnitelmauudistuksen yhteydessä voimme kysyä emeritus professori Juhani Peltosen aikoinaan otsikoimaa tekstiä mukaillen, että "katosiko käsityö Suomen peruskouluista?"

On todettu, että tytöt menestyvät koulussa keskimäärin paremmin kuin pojat, mutta tytöt valitsevat poikia harvemmin tieteen, tekniikan tai teknologian uravaihtoehdoksi (She Figures 2012). Naiset ovat edelleen sekä Suomessa että muualla Euroopassa vähemmistönä teknologia-alojen koulutuksessa ja työelämässä (She Figures 2015). Tutkimusten mukaan tyttöjen on vaikeampi rakentaa suhdettaan teknologiaan, koska heillä on jo lapsuudesta alkaen vähemmän kokemuksia siitä (Mammes 2004). Näyttää siis siltä, että yhteiseen käsityön opetukseen siirtymisen taustalla on ajatus sukupuolten välisestä tasa-arvosta ja tyttöjen tietoisesta ohjaamisesta tekniikan ja teknologian opintoihin. Tämä lienee perusteltua tarkasteltaessa asiaa sukupuolten välisen tasa-arvon näkökulmasta, mutta yksilön valinnan mahdollisuuksien kunnioittamisen näkökulmasta tarkasteltuna nyt tehty muutos on ongelmallinen. Kyse on koulutuspoliittisesta päätöksestä, joka antaa aihetta kysyä, että huomioidaanko tulevaisuuden käsityön opetuksessa oppilaiden omat taipumukset ja kiinnostuksen kohteet riittävästi? Oppilaan näkökulmasta tarkasteltuna Aution (2013) tutkimustulokset eivät tue tällaista muutosta, koska edelleen suurin osa tytöistä $(63 \%)$ valitsisi pelkästään tekstiilityön sisältöjä ja suurin osa pojista (88 \%) pelkästään teknisen työn sisältöjä, jos tällainen olisi mahdollista. Tosin vuosien 1993 ja 2012 välillä tyttöjen kiinnostus teknisen työn tai yhteisen käsityön valintoja kohtaan on lisääntynyt 11 prosenttia, mutta vastaavasti poikien kiinnostus tekstiilityön tai yhteisen käsityön valintoja kohtaan on vähentynyt lähes kahdeksan prosenttia. (Autio 2013.)

Teknologian opetus on erityisen tarpeellista koko ikäluokalle. On silti kriittisesti tarkasteltava sitä, missä määrin tyttöjen omia taipumuksia ja kiinnostuksen kohteita kunnioitetaan käsityöhön liittyvissä valinnoissa. Edelleen ongelmana on, että käsityön oppiaineen rakenteelliset muutokset 
Ainedidaktiikka 1(1) (2017)

koskettavat erityisesti poikia. Sellaiset maaseudun ja Oulun alueen pojat, joiden vahvuusalueita eivät ole lukeminen, kirjoittaminen ja itseilmaisu, ovat menettämässä senkaltaisen käsityön oppiaineen, jonka he kokevat hyödylliseksi ja kiinnostavaksi ja jonka omaleimaisena piirteenä on ollut yksilön valinnan mahdollisuuksien kunnioittamisen ja valinnan vapauteen perustuva sisällöllisesti painotettu opetus.

Myös Deci \& Ryan (1985) toteavat motivaatiota käsittelevässä psykologian perusteoksessa, että mikäli oppilaan käyttäytymistä säätelee jokin ulkoinen kontrolli, yksilö kokee, että tapahtumien kulku ei ole hänen omassa hallinnassaan. Tällöin yksilön itsemääräämisen tunne heikkenee tai jopa katoaa kokonaan. Tämä tilanne vaikuttaa edelleen myös oppilaan itsetuntoon. Opettajat omaksuvatkin usein kontrolloivan pedagogisen tyylin ajatellessaan ymmärtävänsä paremmin, mikä oppilaille on parasta. Näin tehdessään opettajat ajattelevat oppilaan motivaatiota ja sitoutumista vain omasta näkökulmastaan ja kontrolloivat oppilasta ajattelemaan, käyttäytymään ja jopa tuntemaan tietyllä tavalla (Reeve 2009).

Tässä tutkimuksessa saman sisältöiseen käsityön opetukseen osallistuneiden oppilaiden osuus $(\mathrm{n}=144)$ on noin 15 prosenttia kaikista oppilaista. Vuonna 2010 perusopetuksen päättäneistä oppilaista saman sisältöiseen tai eripituisia vaihtojaksoja sisältävään painotettuun käsityön opetukseen seitsemännellä luokalla osallistui 38 prosenttia kaikista oppilaista eli 62 prosenttia oli osallistunut painotetusti vain käsityön toisen sisällön opetukseen (Hilmola 2011). Seitsemännellä luokalla saman sisältöisenä toteutettu käsityön opetus ei siis ole ollut kovin yleistä ja pääosin painotettuna toteutetun käsityön opetuksen aikakaudella sen on todettu olevan poikien mielestä koulun kiinnostavin oppiaine (Jakku-Sihvonen 2013). Edelleen, kun käsityön pakollisen oppimäärän oppitunnit yläluokilla vähenevät nykyisestä 33 prosenttia, voidaan kriittisesti kysyä, kehitetäänkö perusopetusta tyttöjä suosivalla tavalla, poikien kiinnostuksen kohteita kaventamalla.

Olisiko tyttöjen saamiselle osaksi tekniikan ja teknologiakasvatuksen opetusta ollut käytettävissä muita keinoja? Kansainvälisesti STEM aineiden tietoa ja ymmärrystä pidetään elintärkeinä nuorten tulevaisuudelle yhä enemmän teknologisoituvassa yhteiskunnassa ja näin ollen STEM -aineiden koulutus nähdäänkin uutena "kilpavarusteluna", johon julkinen valta on valmis sijoittamaan (Banks \& Barlex 2014). Olisiko myös Suomessa ollut aiheellista perehtyä STEM -aineiden ajatukseen ja kehittää tulevaisuuden haasteisiin vastaavaa perusopetusta juuri tältä pohjalta. Teknisen työn sisällöt mahdollistaisivat matemaattisiin ja luonnontieteellisiin oppiaineisiin liittyvien teoreettisten käsitteiden ja sisältöjen tarkastelun käytännönläheisessä oppimisympäristössä. Varteenotettava vaihtoehto voisi myös olla Pohjois-Amerikassa ja Islannissa käytetty järjestelmä, missä tekstiilityö ja kotitalous muodostavat oman kokonaisuuden (home economics) ja niin ikään teknologiakasvatus koko ikäluokalle tarkoitetun oman oppiaineen. Kouluissa olisi jo tällä hetkellä puitteet laajaalaiseen teknologiakasvatuksen opetukseen. Vastaavasti tekstiilityön sisällöt liittyisivät vahvasti kotitalouteen ja kuluttajakasvatukseen omassa oppiaineryhmässään. Tällöin käsityön erilaiset sisällöt saisivat tukea muilta ja vastaavasti tukisivat muita lähellä olevia oppiaineita. Tällainen ratkaisu 
Ainedidaktiikka 1(1) (2017)

mahdollistaisi sen, että käsityön erilaisia sisältöjä voitaisiin edelleen kehittää omina erikoisaloina niitä lähellä olevissa oppiaineryhmissä, mutta jättää edelleen mahdollisuus sellaisten yhtymäkohtien yhteistyölle, mihin on luontevasti totuttu koko peruskoulun olemassa olon ajan. Joissakin maissa on jo nyt asetettu kansallisia standardeja teknologian opetukselle ja teknologisen lukutaidon kehittämiselle kaikilla koulutustasoilla, mutta yhteistä kehystä sen opettamiselle maailmanlaajuisesti ei ole (de Vries 2005, Cross 2011). Niin Suomessa kuin useissa muissa maissa teknologiakasvatus ei ole erillinen oppiaine perusopetuksen kouluissa, mutta esimerkiksi Saksassa, Australiassa, Iso-Britanniassa ja Alankomaissa teknologian rooli kasvatuksessa on olennainen osa koulutusta niin yläkouluissa kuin lukioissakin (Mativo ym. 2013).

Uudistamalla opetussuunnitelmia koulu pyrkii vastaamaan ajassa tapahtuvien muutosten aiheuttamiin haasteisiin (Rantala 1996, 143). Näin ei käsityön opetuksen kohdalla kuitenkaan ole käynyt kuin sukupuolten välisen tasa-arvon näkökulmasta ja ajatus yhteisestä käsityönopetuksesta on saanut osakseen vuosien varrella paljon kritiikkiä. Kaukisen $(2006,76)$ mukaan käsityöoppiaineen keskeinen ongelma on tällä hetkellä sen väärin perustein tehty oppiainemäärittely lakitekstissä, johon on kietoutunut tasaarvokeskustelu sekä koulutuspolitiikassa valtataistelu tunneista koulun tuntikehyksessä. Olisiko siis Suomessakin aika luopua oppiainekeskeisestä perusopetuksesta ja muodostaa laajempia oppiaineryhmiä, joita opettavat useat asiantuntijaopettajat. Erityisesti teknologiakasvatuksen näkökulmasta tällainen ratkaisu STEM -ajatuksen mukaisesti voisi olla kestävä pohja tulevaisuudelle. Erityisesti jo nyt käytettävissä olevien resurssien tarkoituksenmukainen hyödyntäminen rakentaisi tukevaa pohjaa teknologiakasvatuksen oppiaineryhmälle.

Sternberg (2003) näkee vastaavassa dilemmassa yhdeksi ratkaisuksi sen, että asiaa katsotaan kokonaan uudesta näkökulmasta. Yksi tapa voisi olla tasa-arvon näkeminen myös toisesta eli yksilön tasa-arvon näkökulmasta ja esittää oikeutettu kysymys: Onko tasa-arvon toteutuminen todellisempaa siinä tapauksessa, että kaikki saavat valita taipumustensa ja kiinnostuksensa perusteella mieleisensä käsityön oppisisällön? Edelleen, jos tuntimäärät eivät riitä sekä teknisen työn että tekstiilityön kaikkien oleellisten sisältöjen opettamiseen, niin kumpi on peruskoulun oppilaiden tulevaisuuden kannalta hyödyllisempää - opettaa kaikille tytöille ja pojille teknologiaa vai kaikille tekstiilityötä? Edelleen tulisi entistä tarkemmin miettiä, mitkä ovat yhden peruskoulun oppiaineen todelliset ja realistiset mahdollisuudet tasa-arvon kaltaisen laajamittaisen ja monisyisen yhteiskunnallisen ongelman ratkaisemiseen?

\section{Lähteet}

Allsop, T. (1986). Attitude studies in the OERG Technology project. Teoksessa: J. H. Raat \& M. J. deVries (toim.), What do boys and girls think of technology? Report PATT' workshop. Eindhoven, the Netherlands: Eindhoven University of Technology, 147-150.

Ardies, J., De Maeyer, S. \& Gijbels, D. (2013). Reconstructing the pupils' attitude towards technology survey. Design and Technology Education: An International Journal, 18(1), 8-19. 


\section{Ainedidaktiikka 1(1) (2017)}

Ardies, J., De Maeyer, S., Gijbels, D. \& van Keulen, H. (2015). Students' attitudes towards technology. International Journal of Technology and Design Education, 25(1), 43-65.

Autio, O. 2013. Oppilaiden teknologiset valmiudet - vertailu vuoteen (1993). Kasvatus 44(4), 367-380.

Autio, O., Soobik, M., Thorsteinsson, G., \& Olafsson, B. (2015). The Development of Craft and Technology Education Curriculums and Students' Attitudes towards Technology in Finland, Estonia and Iceland. International Journal of Contemporary Educational Research, 2(1), 22-34.

Banks, F. \& Barlex, D. (2014). Teaching STEM in the secondary school: Helping teachers meet the challenge. New York, NY: Routledge.

Boser, R., Palmer, J. \& \& Daugherty, M. (1998). Students Attitudes Toward Technology in Selected Technology Education Programs. Journal of Technology Education 10(1), 4-17.

Cross, A. (2011). In search of a pedagogy for primary design and technology. Teoksessa: C. Benson \& J. Lunt (toim.) International handbook of primary technology education: Reviewing the past twenty years. London: Sense Publishers, 167-180.

de Vries, M. J. (2005). Teaching about technology: An Introduction to the philosophy of technology for non-philosophers. Dordrecht: Springer.

de Weerd, J. \& Rommes, E. (2012). To beta or not to beta? The role of teachers in the gendered choice of science and technology by secondary school students. Teoksessa: C. Quaiser- Pohl \& M. Endepohls-Ulpe (toim.), Women's choices in Europe: Influence of gender on education, occupational career and family development (ss. 63-78). Münster: Waxmann.

Deci, E. L. \& Ryan, R. M. (1985). Intrinsic motivation and self-determination in human behavior. New York: Plenum Press.

Eagly, A. H. \& Chaiken, S. (1993). The psychology of attitudes. Fort Worth: Harcourt Brace College Publishers.

Endepohls-Ulpe, M., Ebach, J., Seiter, J. \& Kaul, N. (2012). Barriers and motivational factors for taking up a career in a technological field in Germany and Austria. Teoksessa: C. Quaiser-Pohl \& M. Endepohls-Ulpe (toim.), Women's choices in Europe: Influence of gender on education, occupational career and family development (ss. 79-93). Münster: Waxmann.

Erätuuli, M., Leino, J. \& Yliluoma, P. (1994). Kvantitativiset analyysimenetelmät ihmistieteissä. Helsinki: Kirjayhtymä.

Grant, M. \& Harding, J. (1987). Changing the polarity: International Journal of Science Education 9(3), 335-342.

Hilmola, A. (2011). Käsityö. Teoksessa: S. Laitinen, A. Hilmola \& M-L. Juntunen (toim.), Perusopetuksen musiikin, kuvataiteen ja käsityön oppimistulosten arviointi 9. vuosi-luokalla (ss. 157-237). Koulutuksen seurantaraportit 2011:1. Helsinki: Opetushallitus.

Jakku-Sihvonen, R. \& Komulainen, E. (2004). Perusopetuksen oppimistulosten metaarviointi. Arviointi 1/2004. Helsinki: Yliopistopaino.

Jakku-Sihvonen, R. (2013). Sukupuolenmukaista vaihtelua koululaisten oppimistuloksissa ja asenteissa. Opetushallitus. Koulutuksen seurantaraportit 2013:5.

Johnsson, S. \& Murphy, P. (1986). Girls and physics. Department of education and science, London: Kapiyo, R.J.A.

Kantola, J. (1997). Cygnaeuksen jäljillä käsityönopetuksesta teknologiseen kasvatukseen. Jyväskylä studies in education, psychology and social research; 133. Jyväskylä: Jyväskylän yliopisto.

Kärnä, P. \& Rautopuro, J. (2013). Mitä oppimistulosten taustalla? Teoksessa: A. Räisänen (toim.) Oppimisen arvioinnin kontekstit ja käytännöt (ss. 187-211). Raportit ja selvitykset 2013:3. Helsinki: Opetushallitus.

Kaukinen, L. (2006). Käsityöoppiaineiden arvo ja merkitys sekä opettajankoulutuksen järjestäminen. Teoksessa: R. Jakku-Sihvonen (toim.), Taide- ja taitoaineiden merkityksiä (ss. 76-89). Teatterikorkeakoulun julkaisusarja no. 39. Helsinki: Yliopistopaino.

Komiteanmietintö (1970). A 5. Peruskoulun opetussuunnitelmakomitean mietintö II. Oppiaineiden opetussuunnitelmat. Helsinki: Valtion painatuskeskus.

Kuusi, H., Jakku-Sihvonen, R. \& Koramo M. (2009). Koulutus ja sukupuolten tasa-arvo. Sosiaali- ja terveysministeriön selvityksiä 2009:52. Helsinki: Yliopistopaino. 


\section{Ainedidaktiikka 1(1) (2017)}

Mammes, I. (2004). Promoting girls' interest in technology through technology education: A research study. International Journal of Technology and Design Education 14(2), 89-100.

Matikainen, J. (2006). Asenteen oppiminen - kontekstuaalinen näkökulma. Kasvatus $37(3), 276-289$.

Mativo, J. M., Womble, M.N. \& Jones, K. H. (2013). Engineering and technology students' perceptions of courses. International Journal of Technology and Design Education, 23(1), 103-115.

Mattila, L. (2005). Perusopetuksen matematiikan kansalliset oppimistulokset 9. vuosiluokalla 2004. Oppimistulosten arviointi 2/2005. Helsinki: Opetushallitus.

McGuire, W. J. (1985). Attitudes and attitude change. Teoksessa: G. Lindzay \& E. Aronson (toim.), Handbook of social psychology. Volyme II. Special fields and applications (ss. 233-304). New York: Random House.

Metsämuuronen, J. (2003). Tutkimuksen tekemisen perusteet ihmistieteissä. Helsinki: International Methelp ky.

Metsämuuronen, J. (2009). Metodit arvioinnin apuna. Perusopetuksen oppimistulosarviointien ja -seurantojen menetelmäratkaisut Opetushallituksessa. Oppimistulosten arviointi 1/2009. Helsinki: Opetushallitus.

Opetushallitus. (2004). Perusopetuksen opetussuunnitelman perusteet 2004. Vammala: Vammalan Kirjapaino Oy.

Opetushallitus. (2014). Perusopetuksen opetussuunnitelman perusteet 2014. Tampere: Juvenes Print - Suomen yliopistopaino Oy.

Opetushallitus. (2015). Käsityön opetuksen järjestäminen. Viitattu 30.3.2016. http://www.oph.fi/ajankohtaista/verkkouutiset/101/0/kasityon_opetuksen_jarjestaminen

Parikka, M. (1998). Teknologiakompetenssi. Teknologiakasvatuksen uudistamishaasteita peruskoulussa ja lukiossa. Jyväskylä Studies in Education, Psychology and Social Research 141. Jyväskylä: Jyväskylän yliopisto.

POL (628/1998). Perusopetuslaki. Viitattu 3.3.2016. http://www.finlex.fi/fi/laki/ajantasa/1998/19980628.

Popham, W. (1994). "Educational assessment's lurking lacuna: The measure of affect." Education and Urban Society, 26(4), 404-416.

Pöllänen, S. (2002). Yhteinen käsityö sukupuolten tasa-arvon näkökulmasta tarkasteltuna. Teoksessa: P. Nuutinen \& E. Savolainen (toim.) 50 vuotta opettajankoulutusta Savonlinnassa. Joensuun yliopisto: Savonlinnan opettajankoulutuslaitos.

Rantala, J. (1996). Opetussuunnitelmauudistus ei ole toistaiseksi tuonut muutoksia historianopetukseen. Teoksessa: S. Tella (toim.) Nautinnon lähteillä: Aineen opettaminen ja luovuus. Tutkimuksia 163. Helsingin yliopiston opettajankoulutuslaitos, $143-148$.

Reeve, J. (2009). Why Teachers Adopt a Controlling Motivating Style Toward Students and How They Can Become More Autonomy Supportive. Educational Psychologist 44(3), 159-175.

She Figures (2012). Gender in research and innovation. Statistics and indicators. European Commission. Available in: http://ec.europa.eu/research/science-society/document_library/pdf_06/she-figures-2012_en.pdf

She Figures (2015). Gender in research and innovation. Statistics and indicators. European Commission. Preliminary results. Available in: http://ec.europa.eu/research/swafs/pdf/pub_gender_equality/she_figures_2015leaflet-web.pdf\#view=fit\&pagemode=nonefit\&pagemode=none

Sternberg, R. (2003). Creative Thinking in the Classroom. Scandinavian Journal of Educational Research 47(3), 325-338.

Streumer, J. (1988). Evalueren van techniek. Enschede, Universiteit van Twente.

Van Rensburg, S., Ankiewicz, P. \& Myburgh, C. (1999). Assessing South Africa Learners' Attitudes Towards Technology by Using the PATT (Pupils' Attitudes Towards Technology) Questionnaire. International Journal of Technology and Design Education 9, 137-151.

Vettenranta, J., Välijärvi, J., Ahonen, A., Hautamäki, J., Hiltunen, J., Leino, K., Lähteinen, S., Nissinen, K., Nissinen, V., Puhakka, E., Rautopuro, J. \& Vainikainen, M.P. (2016). PISA 15 Ensituloksia. Huipulla pudotuksesta huolimatta. Opetus- ja kulttuuriministeriön julkaisuja 2016:41. 
Ainedidaktiikka 1(1) (2017)

Virtanen, S., Räikkönen, E. \& Ikonen, P. (2015). Gender-based motivational differences in technology education. International Journal of Technology and Design Education 25(2), 179-211. 


\title{
Ainedidaktiikka 1(1) (2017)
}

\begin{abstract}
As early as 1970 a committee report suggested that both technical and textile crafts should be compulsory for both boys and girls. After this, the national curriculum has been revised several times. However, a suitable solution for the curriculum of craft education has not been found. In this article, students' attitudes towards craft education were examined. The research data was collected during the school years 2013-2014. The research design is quantitative and the data $(N=982)$ represents the whole country demographically. First the implementation of craft education in the basic level is described. The theoretical starting point of this article is the earlier research related to the attitudes towards craft education. The main research question is: to what extent do girls' and boys' attitudes related crafts subject differ from each other. According to the empirical results, the attitudes of the pupils who have participated in the emphasised technical craft are distinctly more positive than the corresponding attitudes of the pupils who have participated in shared craft education (as much technical craft and textile craft). In addition, the pupils who have participated in the emphasised technical craft take part in the voluntary craft education more often when compared with the pupils who have participated in the shared craft education. What is more, the justifiable question of the other viewpoint in respect for the possibilities of the choice of the individual arouses: are all the students given a sufficient opportunity to emphasise the study of the crafts which are in accordance with their own interest and its talent?
\end{abstract}

attitudes, gender, craft education, technical craft, textile craft 